\title{
Global Climate Change as Perceived by Elementary School Teachers in Yogyakarta, Indigenous Psychology Approach
}

\author{
Aquilina Tanti Arini ${ }^{1}$, Ratna Juwita Ghazali ${ }^{2}$, Arti Satiti ${ }^{3}$, Mintarsih $^{4}$, \\ Yosua Kamali ${ }^{5,}$ Kwartarini W Yuniarti ${ }^{6}$ \\ ${ }^{1}$ Faculty of Psychology Universitas Sanata Dharma Yogyakarta; \\ 2Elementary School Teacher in SDN Bhayangkara, Yogyakarta; \\ ${ }^{3}$ Elementary School Teacher in SDN Bhayangkara, Yogyakarta \\ ${ }^{4}$ Elementary School Teacher in SDN Samirono, Sleman \\ ${ }^{5}$ Faculty of Psychology, Universitas Sanata Dharma Yogyakarta \\ ${ }^{6}$ Faculty of Psychology, Universitas Gadjah Mada
}

\begin{abstract}
This study is aimed to describe how the global climate change was perceived by teachers of elementary schools. The subjects were 111 teachers from 7 elementary schools in Yogyakarta City and Sleman district. The data was collected using open-ended questions (including perceptions about the weather, feelings evoked by global warming words and free responses related to global warming issues). The data was analysed using the technique of qualitative and quantitative content analysis with an Indigenous Psychology Approach. The results showed that only one teacher reported that there was no weather anomaly, while 110 teachers reported that they perceived weather anomaly. Of those who perceived weather anomaly mostly referred to natural conditions (including global climatic condition and environmental destruction) and human behaviour as its root causes. Responses about feelings evoked by global warming words were classified into three categories, i.e. emotional, physical and irrelevant responses. Free responses about global warming were classified into four categories respectively from the highest frequency of responses: prevention (including statement "must be prevented", prevention behaviours and prevention efforts), states (including the weather states and feeling), causes (including technological advances and human behaviour generally), and others. The research finding was discussed in the frame of environmental concern as a means of character education in elementary schools.
\end{abstract}

Keywords: elementary school teacher, indigenous psychology approach, global climate change, weather anomaly

Global climate change is a long-term climate change that is caused by natural variability and human activities. Human activities which are responsible for these issues are activities that result in greenhouse gas emissions, for example, the use of fossil fuels and deforestation. The accumulation of these gases in the atmosphere leads to an increase of the earth's temperature, which causes global warming and an accelerated global climate change (Intergovernmental Panel on Climate Change, 2007, 2014).

\footnotetext{
${ }^{1}$ Address for correspondence:

aquilinata@yahoo.co.id
} 
Climate change becomes a global issue, especially since the ratification of the Kyoto Protocol in 1998 (United Nations, 1998). Since then, many countries in the world including Indonesia have given their serious attention to the movement of mitigation and adaptation to global climate change. American Psychological Association (APA Task Force on the Interface between Psychology and Global Climate Change, in press) stated that the issue of global climate change had positive impacts on the collective awareness of environmental protection. This collective awareness was rooted from the values that directed individual behavior. Therefore, in our study, we used this issue to identify not only the beliefs about climate change itself but perhaps we could discover values that underlined it.

Some studies suggested that we could elicit the society's values through the issue of global climate change. Research finding from Newcastle Australia (Harriet, 2000) identified that the global climate change issue was understood on local knowledge, values, and moral responsibility. Similarly, a qualitative study conducted by Fischer, Peters, Vavra, Neebe, and Megyesi (2011) found respondents' beliefs about the factors that shaped behavior instead, such as people's tendency to be self-centered due to their insatiable consumption habits and being money-oriented. Their study was about the belief and knowledge of climate change issues and energy on the respondents in 5 European countries.

This study aimed to describe public perception on global climate change issues. The public in this study were teachers of elementary schools. From teachers' perception on this issue, we wanted to know whether their perception reflected concerns over environmental issues and also the beliefs and values that are associated with environmental concerns.

Values refer to what we think is important in our life. Each of us hold various different values (e.g. achievement, security, benevolence) with varying degrees of importance. A particular value may be important to one person but may be unimportant to another (Schwartz, 2012). Some values are closely related to environmental concerns. The definition of environmental concern is "the degree to which people are aware of problems regarding the environment and support the effort to solve the problems and or indicate the willingness to contribute personally to their solution" (Dunlap \& Jones as cited in Alibeli \& White, 2011). Previously, Fransson and Garling (1999) reviewed the definition of environmental concerns from literature. They summarized that environmental concern was defined into two concepts, (1) an evaluation or attitude towards facts, self and other's behavior that had environmental consequences and (2) the general attitude or value orientation.

Fransson and Garling (1999) described value orientation previously suggested by Stern that was associated with environmental concern. The value orientation included (1) Environmental concern which represents a way of thinking called New Environmental Paradigm (NEP). NEP was a paradigm that views humans as an integral part of the whole of natural ecosystems; (2) environmental concern associated with anthropocentric altruistic values, that was, people care for the environmental quality because they believed that the damage to the environment threatens human well-being, so the focus of concern was on humans, not of nature; (3) environmental concern 
associated with self-interest; (4) Environmental concern associated with religious or post-materialistic values.

Alibeli and White (2011) examined the tripartite model of environmental concern proposed by Stern, et al. Previously Stern, et. al. (as cited in Alibeli \& White, 2011) proposed a model in which environmental concerns consisted of three interrelated dimensions and tested their model on a limited sample. This value orientation included altruistic social values (highlight concerns about the welfare of another human), Biospheric values (concern for non-human species or biosphere) and egoism or self-interest orientation that was best described by "not in my backyard" attitude. Empirically, Allibeli and White (2011) tested these models in the United States population with large, national and representative samples. Their research finding supported the tripartite model proposed by Stern, et al.

The association between values and environmental concerns was also revealed in the study conducted by Nordlund and Garvill (2002) to 1414 people in Sweden. Their study showed that compared with individuals who gave their priority to selfenhancement values, those who gave priority to self-transcendent values had higher awareness of the threat to the environment and perceived stronger moral obligations to protect the environment. Their research findings also indicated that self-transcendence was associated with ecocentrism, but not with anthropocentricism; Self-enhancement had a negative effect on ecocentrism and a positive effect on anthropocentrism. Ecocentrism represented the belief that the ecosystem had an intrinsic value, therefore it should be protected, whilst anthropocentricism was a belief that we should protect the environment because of its effect on human welfare.

The relevance of this study to character education

Character refers to main values that build individuals and manifest in personal attitude and daily behaviors (Samani \& Hariyanto, 2012). The main values that the Indonesian character education will build include honesty, intelligence, strength and care (jujur, cerdas, tangguh and peduli). These values are grounded from olah hati, olah pikir, olah raga and karsa or consistent practice of good conscience, good thinking, physical exercise and goodwill (Samani \& Hariyanto, 2012).

Teachers priorities are usually dedicated towards values related to achievement. It is nonetheless too narrow in the context of building the students' character. Educating students to hold their concerns over their surrounded environment, inclusive of the natural environment which is important to develop strong characters (good characters) in children.

The implementation of character education in Indonesia is integrated with the school curriculum program. There are 17 points of competency standards as the study outcomes in Indonesian elementary schools, one of which involves cinta dan peduli lingkungan (love and care to the environment). The expected characters from those study outcomes are peduli (care, concern) and tanggung jawab (responsibility) (Judiani, 2010; Samani \& Hariyanto, 2012, ).

In order to build environmental concerns in the school setting, on February 21, 2006, four Indonesian ministry departments (including the Department of Environment, the Department of National 
Education, the Department of Religious Affairs, and the Department of Home Affairs) designed a program named Adiwiyata Program (Panduan Adiwiyata, 2011). The purpose of this program was to create effective school conditions so the school communities could participate in efforts of saving the environment and sustainable development. Although not all elementary schools in Indonesia were involved in this program, at least the efforts of this program dissemination raised environmental awareness to many schools.

Study on teachers' values needs an implicit question to minimize social desirability bias. Therefore, in this study, we considered that the global climate change issue could be used as a cue to elicit values other than teachers' beliefs about global climate change itself. On the other hand, global climate change is a relatively new technical term that was not easily understood by lay people, even in developed countries, as shown by studies of Harriet (2000) and Etkin and Ho (2007). Harriet (2000) identified some studies that showed misconceptions about global climate change among lay people in Australia, for example, the confusion about climate change and stratospheric ozone depletion. Also, Etkin and Ho (2007) found that there were misconceptions about climate change, greenhouse gas, and ozone layer depletion. Therefore, in this study, our focus was on the familiarity of this issue for lay people, regardless of the accuracy of their knowledge in regards to global climate change. In order to obtain the research finding specifically in context, we used Indigenous Psychology approach, briefly introduced in the next section.

\section{Indigenous psychology}

Indigenous Psychology is a field of psychology that extends the boundary and substance of General Psychology. The similarity between the two is in seeking findings, facts, principles, and laws of human behavior universally. The difference between the two is the point to initiate the research. General Psychology assumes that current theories of psychology are universal in nature, and research on general psychology seeks to discover decontextualized, mechanical and universal principles. Indigenous Psychology, however, questions the universality of existing psychology theories and attempts to discover universality of theories in social, cultural and ecological contexts. Indigenous Psychology represents an approach which explicitly incorporates content (i.e. meaning, values, and beliefs) and contexts (i.e. family, social, cultural and ecological) into a research design (Kim, Yang, and Hwang, 2006).

This study is aimed to describe what people said about global climate change or global warming. Although this study was not aimed to theory building, Indigenous Psychology could be used as an approach to obtain the data that was interpreted as original as possible. As Indigenous Psychologist suggested that we had to incorporate context into our design, we used Indigenous Psychology approach in process of data analysis.

\section{Method}

This study used survey method. The data analyzed by the technique of qualitative and quantitative content analysis. Hsieh and Shanon (as cited in Cho \& Lee, 2014) defined qualitative content analysis as "a research method for subjective interpretation of the content text data through the systematic classification process of coding and identifying themes or pattern". 
The Process of data analysis conducted with Indigenous Psychology approach that was proposed by Kwartarini W. Yuniarti. Using this approach, the qualitative data must be analyzed by at least three people who had the characteristics as close as possible to the characteristics of the population plus a senior analyst (Yuniarti, 2013). In this approach, the process of data analysis was conducted in several stages. The people from population did the data analysis at the first stages and senior analyst at the next stages. The minimum number of three people in stage 1 were set up to minimize subjectivities. The identified themes from qualitative content analysis after then were summed into a percentage using Microsoft Excel 2010.

\section{Instrument}

In order to obtain original responses from respondents, we constructed open-ended questions. Previously, we asked about the familiarity with the terms related to global climate change (i.e: pemanasan global, prubahan iklim global, cuaca ekstrem, penipisan lapisan ozone) to 64 respondents who attended an Indigenous Psychology workshop held by CICP Universitas Gadjah Mada on March 2015 as a preliminary survey. The result identified that global warming was a term that was familiar by all respondents and most of them related their experience concerning local weather to global climate change. Based on this finding, global warming terms and the weather perception were used to formulate the open-ended questions.

The open-ended questions in this study were part of the complete questionnaire that comprised questions about teachers' conception in regards to global warming, self-report about proenvironmental behavior, worldview and myth of nature. In this study, we focused on exploring teachers' beliefs about global warming (or global climate change), including (1) Teachers' perceptions about weather changes and its causes (2) Response of feelings as evoked by global warming word (3) Free responses about global warming.

Before collecting the data, this questionnaire was implemented on a few respondents (we selected 5 respondents that had characteristics resemble the population) to ensure that the open-ended questions were understandable.

\section{Data collection}

Respondents in this study involved 111 elementary school teachers from 7 elementary schools in Yogyakarta City (i.e: SDN Bhayangkara, SDN Serayu) and Sleman District (i.e: SDN Samirono, SDN Percobaan II, SDN Karangwuni, SDN Minomartani, SDN Malang Rejo). The characteristics of respondents can be seen in Table 1.

Table 1.

Characteristics of respondents

\begin{tabular}{cl}
\hline Demography & \multicolumn{1}{c}{ Description } \\
\hline Age & Range $: 25-60$ \\
& Mean $: 46$ \\
Gender & Male $: 27$ \\
& Female $: 78$ \\
& NA $: 6$ \\
\hline
\end{tabular}

We collected the data in May and June 2015. The timing of the data collection was unfortunately simultaneous with the timing when elementary schools prepared National Examination for their students. Therefore, by using convenience sampling_i.e. non-probability sampling where subjects were selected due to their convenience accessibility and proximity to the researcher $\_$we attended some schools and "door to door" asked permission to 
school principals to collect data on teachers under their management. Subsequently, in order to make sure that the questionnaire was responded by respondents themselves, we gathered them in one class and distributed the questionnaires which they returned immediately thereafter.

\section{Data analysis}

We used content analysis with Indigenous Psychology approach to analyze the data. At stage 1, the three teachers identified the keywords on respondents responses for then coding them into the themes. We recruited stage 1 data analyst based on knowledgeability criterion with the rationale that they had the capability to analyze the data. We recruited the data analyst from the population and to meet the knowledgeability requirement, they were at least Bachelor's degree (S1). The brief training was provided to them so they were ready to analyze the data both in skill and the assertiveness in their discussions. At stage 2 , the senior analysts categorized the result of thematic coding into a broader level of categories and implemented the quantitative content analysis facilitated by Microsoft Excel 2010.

\section{Result}

Teachers' perception about weather change and its causes

From 111 respondents, only one teacher reported that there was no weather change while the other respondent perceived the weather change - which is the recent weather difference from normal weather patterns or in other words, the weather anomaly. The description of causes of weather anomaly stated by the 110 respondents could be seen in Table 2 .

As Table 2 showed, the global climatic condition was referred to as the cause of weather anomaly by most of the respondents (54.90\%) with global warming as a dominant response. These results indicated that global warming was familiar to the respondents, consistent with the previous studies.

As shown in Table 2, only a few respondents $(1.80 \%)$ associated the anomaly of weather with pollution. Moreover, themes about human behavior that were seen as the cause of weather anomaly consisted of responses about the effect of technology on environmental damage $(8.11 \%)$. These findings may indicate that only a few respondents showed concerns about how their personal behavior contributed to the weather anomaly.

Feeling responses as evoked by global warming word

From this question, we uncovered various responses, not only about feeling but also physical sensations and other responses that were irrelevant to feeling. The statistics of each theme could be seen in Table 3.

Table 2.

Thematic classification about causes of weather anomaly $(\mathrm{N}=111)$

\begin{tabular}{ll}
\hline \multicolumn{1}{c}{ Categories } & \multicolumn{1}{c}{ Descriptive statistic (\%) } \\
\hline Global Climatic & Global warming (32.43\%); climate change (18.92\%); damage of \\
Condition & ozone layer (3.60\%) \\
Environmental Condition & $\begin{array}{l}\text { Pollution }(1.80 \%) ; \text { environmental damage (14.41\%); reduced the } \\
\text { number of trees (12.61\%) }\end{array}$
\end{tabular}


Human Behaviour

Others
Human behaviour (8.11\%)

Others $(2.70 \%)$

Table 3

Thematic classification about feeling responses $(\mathrm{N}=111)$

\begin{tabular}{ll}
\hline Categories & \multicolumn{1}{c}{ Descriptive statistic (\%) } \\
\hline Emotion & Worry (27.03\%); Concerned (18.2\%); Disappointment (1.8\%) \\
Physic & Hot weather (22.52\%); Discomfort (7.21\%) \\
Others & Irrelevant responses (20.72\%) \\
NA & NA $(2.70 \%)$ \\
\hline
\end{tabular}

The emotion themes like worry, prihatin (concerned) and disappointment indicated that teachers experienced a negative affect over global warming. It reflected that they perceived global warming as a risk since the affect was an important sign of perceived risk (Leiserowitz, 2006, Peters, Burraston, \& Mertz, 2004; Slovic, Finucane, Peters, \& MacGregor, 2004).

The other themes about feelings as evoked by the word "global warming" were physical sensations (29.73\%). This reminded us to be cautious about the deep structure of the local language. Apparently, questions about feelings by the word perasaan in the Indonesian language had multiple meanings as shown by this finding, including emotion, physical sensation (for instance: rasanya panas/It feels hot) and also irrelevant responses that were detected with a moderately high percentage $(20.72 \%)$. The example of irrelevant responses that may represent the worries of the catastrophic effect of global warming were: bumi semakin tua (the earth is becoming older), kiamat semakin dekat (the end of the world is near),or impact of global warming on the environment: air susah menyerap di tanah (water cannot be absorbed into the earth), etc. These various responses to questions about feelings suggested to the next researcher to be more perceptive towards indigenous languages.

\section{Free responses about global warming}

Previous studies in regards to public perception of global climate change suggested that global climate change was a complex issue that involved multiple facets, such as psychological, sociopolitical, cultural, and economic facets. Therefore, asking teachers to write down their free responses to these issues functioned to allow them space to express anything that popped up in their minds. From this question, we expected to elicit the actual beliefs about the issue that was associated with global warming in the teachers' mind. Categories of teachers' responses could be seen in Table 4.

Table 4

Thematic classification of free responses $(\mathrm{N}=111)$

\begin{tabular}{ll}
\hline Categories & \multicolumn{1}{c}{ Descriptive statistics (\%) } \\
\hline Prevention & $\begin{array}{l}\text { Statement "must be prevented" } \\
(12.61 \%), \text { Prevention behaviour } \\
(48.66 \%), \text { Prevention effort }\end{array}$ \\
& $(5.40 \%)$ \\
States & Feeling and weather $(12.31 \%)$ \\
Causes & $\begin{array}{l}\text { Technology }(3.60 \%) \& \text { human } \\
\text { behaviour }(6.31 \%)\end{array}$ \\
Others & Others $(5.4 \%)$ \\
NA & NA $(5.4 \%)$ \\
\hline
\end{tabular}

As shown in Table 4, prevention was the response with the highest frequency $(66.67 \%)$, followed by a statement about 
states, causes, others and abstain. The theme from prevention categories that mostly appeared was prevention behavior, responded by $48.66 \%$ of all respondents. Sub-themes of prevention behaviors were reforestation (reboisasi) and maintaining environmental sustainability (36.94\%), preventing pollution $(6.31 \%)$ and management of building (5.41\%). Subthemes of prevention efforts were opinions about the urgency of government's roles and for environmental education. We inferred that this result reflected the teachers' belief that humans had control over nature.

\section{Discussion}

This study is aimed to describe teachers' perception about global climate change. Through this study, we expected to discover values or beliefs that underlined their perception as the studies by Fischer, et al. (2011) and Harriet (2000) have shown. Compared with the study of Fischer, et al., and Harriet which used focus group discussion, we utilized a survey with openended questions to collect data and conducted a qualitative content analysis with Indigenous Psychology Approach as proposed by Yuniarti (2013).

The result of this study showed that most of our respondents (1) referred to global climatic and environmental conditions as root causes of weather anomaly; (2) delivered negative emotions as evoked by the word "global warming"; (3) mentioned the urgency of prevention for coping with global warming. It was clear that these findings reflected the perceived risks of global warming among most of our respondents. People perceived risks when they felt that the challenges or harmful events would come to them (Denney, 2005) and they were able to make choices actively to approach or avoid them (Yamori, 2007). In the context of global climate change, those choices were adaptation or mitigation.

This study found that almost all respondents showed concerns of global warming. It might reflect the existence of collective responsibility values on teachers. Although we could not identify specific values underlining their concerns (be they anthropocentric, biocentric or self-interest, self-transcendence or self-enhancement), regarding the relevance of this study to character education by means of environmental concerns, this finding gave us an optimistic expectation that teachers would be involved in the environmental education through their attitude and daily behaviors.

We expected that positive attitudes towards the environment as teachers showed in this study would manifest into their daily behaviors. In order to facilitate the congruency of their behavior to their attitude, school management could support them by providing facilities. Referring to Fuji (2006) that attitude toward frugality would be an effective means to promote pro-environmental behaviors, school management could facilitate the realization of pro-environmental behaviors more effectively by means of programs (for example organizing an intra-school competition among the classes on the green and clean environment issues), tools (for example setting aside garbage cans, maintaining chalkboard and chalks instead of using LCD in classrooms) and infrastructures (e.g. designing school building with big windows for good ventilation and illumination so as to reduce electricity usage, etc.).

The research findings showed that only a few respondents mentioned pollution. These findings indicated that 
promoting a green environment to prevent global warming seemed to be familiar to teachers, relative to fossil fuel emission for instance in electricity usage and transportation. In fact, fossil fuel emission causes the accumulation of $\mathrm{CO} 2$ in the atmosphere which increases greenhouse gases and results in heightening of the earth's temperature which leads to global warming (IPCC, 2014). This weak association between global warming and fossil fuel emission made by teachers may be caused by their lack of knowledge.

The weak association_in terms of memory system_ between global warming and pollution, as well as fossil fuel energy consumption, such as electricity usage and car use, might be caused by a conflict of interest, in addition to a lack of knowledge. The research conducted by Ohler and Bilger (2014) to 33,000 households in Missouri identified that people did not reduce their electrical use, even though they understood whilst doing so was socially important. Their research finding supported the notion that global climate change and clean air suffered from the tragedy of the commons_that was every individual acting independently according to their own self-interest behave contrary to the common good of all users by depleting the shared resource system_. Furthermore, in the Ohler's and Bilger's study, selfinterestadesset had a significant impact on energy-saving behaviors, namely, their concern over comfort or cost of energy. As concerns over comfort increased, individuals were less likely to report engaging in energy-saving behaviors, such as using a power-strip, unplugging rechargeable batteries, and lowering the water heater temperature. Also as concerns over energy costs increased, individuals were more likely to report engaging in energy-saving behaviors. In our study, we presumed that along with the increasing welfare of teachers since certification programs that increased their income significantly, it was likely that their concerns over comfort would increase too, This presumption still needs to be further explored in the next study.

The result of Ohler's and Bilger's study was consistent with the study of Fuji (2006) of 341 Japanese respondents, Tadessse (2009) on 400 respondents in Mekkele Ethiopia, and Whitmarsh (2009) on 589 respondents from Hampshire, a county in southern England. Fuji (2006) found that the attitude toward frugality had positive effects on gas and electricity reduction, while environmental concerns had positive effects solely on garbage reduction. That result was reinforced by Tadesse (2009) that the attitude of environmental concerns was associated with household waste separation and disposal. Furthermore, similar to those studies, the study of Whitmarsh (2009) found that recycling was the most popular activity related to the concerns for climate change, while energy conservation was generally done for reasons unrelated to the environment, for example, to save money or for health concerns. From those studies, it seemed that educating people to adopt proenvironmental behaviors, such as garbage reduction, was probably simpler and generated a lesser conflict of self-interest than expecting them to show energy-saving behaviors.

\section{Conclusion}

This study found that the elementary school teachers saw the global climate change as an environmental problem. Most of them said the importance of reforestation (reboisasi) and maintaining environmental sustainability as a precaution. 
Our conclusion was drawn from limited respondents $(\mathrm{N}=111)$ from 7 elementary schools that incidentally gave us the permission for data collection. Therefore, since this study used convenience sampling we could not claim that our finding could be generalized over teacher population in Yogyakarta. However, we found no extreme divergence in our data, so we argued that these results might represent teacher population in Yogyakarta. Nevertheless, this argument needed to be proven in the next study with a larger and representative sample.

\section{Suggestion}

Only a few respondents mentioned pollution as a cause of global warming. We presumed that it might be caused by lack of knowledge and conflict of interest. This presumption still needs to be further explored in the next study.

\section{References}

Alibeli, M. A. \& White, N. R. (2011). The structure of environmental concern. International Journal of Business and Social Science, 2(4), 1-8

American Psychological Association, Task Force on the Interface between Psychology and Global Climate Change (In Press). Report of the APA task force. Psychology and global climate change: addressing a multi-faceted phenomenon and set of challenges.

Cho, J. Y. \& Lee, E. H. (2014) Reducing confusion about grounded theory and qualitative content analysis: similarities and differences. The Qualitative Report, 19 (64), 1-20

Denney, D (2005) Risk and society. London: Sage Publications
Etkin, D. \& Ho, E. (2007) Climate change: perceptions and discourse of risk. Journal of risk research, 5: 623-641

Fischer, A., Peters, V., Vavra, J., Neebe, M., \& Megyesi, B. (2011). Energy use, climate change, and Folk Psychology: does sustainability have a chance? Result from a qualitative study in five European countries. Global Environmental Change, 21, 1025-1034. http://doi.org/10.1016/j.gloenvcha.2011 .04 .008

Fransson, N. \& Garling, T. (1999). Environmental concern: conceptual definition, measurement methods, and research findings. Journal of Environmental Psychology, 19, 369-382

Fuji, S. (2006). Environmental concern, attitude toward frugality, and ease behavior as determinants of proenvironmental behavior intentions. Journal of Environmental Psychology, 26, 262-268

Harriet, B. (2000) Common knowledge? Public understanding of climate change in Newcastle, Australia. Public understanding of science, 9, 313-333

Intergovernmental Panel on Climate Change (2007). FAQ: How do human activities contribute to climate change and how do they compare with natural influence? Working Group 1, contribution to IPCC fourth assessment report. Retrieved from http://oceanservice. noaa.gov/education/pd/climate/factshe ets/howhuman.pdf, download on August 5, 2014

Intergovernmental Panel on Climate Change (2014). Climate change 2014. mitigating of climate change. (Powerpoint). Working Group 3, contribution to IPCC fifth assessment report

Judiani, S. (2010). Implementasi pendidikan karakter di Sekolah Dasar 
melalui penguatan pelaksanaan kurikulum. Jurnal pendidikan dan kebudayaan, 16, edisi khusus III: 280289.

Kim, U., Yang, K. S., \& Hwang, K. K., (2006). Contributions to Indigenous and Cultural psychology understanding people in context. New York: Springer Science+business Media, Inc

Leiserowitz, A. (2006). Climate change risk perception and policy preferences: the role of affect, imagery, and values. Climate Change, 77, 45-72. http://doi.org/10.1007/s10584-006-9059$\underline{9}$

Nordlund, A. M. \& Garvill, J. (2002). Values structures behind pro-environmental behavior. Environment and Behavior, 34(6), 740-756. http://doi.org/10.1177/00139160223724 4

Ohler, A. M. \& Bilger, S. M. (2014). Does environmental concern change the tragedy of the commons? Factors affecting energy saving behaviors and electricity usage. Ecological Economics, 1007, 1-12

Panduan Adiwiyata. (2011). Panduan adiwiyata sekolah peduli dan berbudaya lingkungan. Kerjasama Kementrian lingkungan Hidup dengan Kementrian Pendidikan dan Kebudayaan. Jakarta: Asdep Urusan Penguatan Inisiatif Masyarakat Deputi Bidang Komunikasi Lingkungan dan Pemberdayaan Masyarakat Kementrian Lingkungan Hidup.

Peters, E. M. Burraston, B. \& Mertz, C. K (2004). An Emotion-based model of risk perception and stigma susceptibility: cognitive appraisals of emotion, affective reactivity, worldviews, and risk perceptions in the generation of technological stigma. Risk Analysis, 24 (5), 1349-1366

Samani, M. \& Hariyanto. (2012). Pendidikan karakter. Konsep dan model. Bandung: PT Remaja Rossdakarya Offset

Schwartz, S. H. (2012). An Overview of the Schwartz theory of basic values. Online reading in Psychology and Culture, 2(1), 128. doi: $10.9707 / 2307.0919 .1116$

Slovic, P., Finucane, M. L., Peters, E., \& Mac Gregor. (2004). Risk as analysis and risk as feelings: Some thoughts about affect, reason, risk, and rationality. Risk Analysis, 24(2), 311-322

Tadesse, T. (2009). Environmental concern and its implication to household waste and disposal: Evidence from Mekelle, Ethiopia. Resources, Conservation and Recycling, 53, 183-191

United Nations. (1998). Kyoto Protocol to the United Nations Framework, Convention on Climate Change.

Whitmarsh, L (2009). Behavioral responses to climate change: Asymmetry of intention and impacts. Journal of Environmental Psychology, 29, 13-23. http://doi.org/10.1016/j.jenvp.2008.05.0 $\underline{03}$

Whitmarsh, L. (2009) What's in a name? commonalities and differences in public understanding of "climate change" and "global warming" Public Understanding of Science, 18(4), 401-420

Yamori, K. (2007). Disaster risk sense in Japan and gaming approach to risk communication. International Journal of Mass Emergencies and Disasters, 25(2), 101-131

Yuniarti, K. W. (2013) Psikologi Indigenous. Saatnya menentukan keilmuan dari tanah air. Pidato Pengukuhan Guru Besar. Universitas Gadjah Mada 
i. This research was funded by AAICP (Asian Association of Indigenous and Cultural Psychology).

ii. We thank to Mrs. Dr. Wenty M Mirza, S.Psi, M.A, director of CICP faculty of Psychology, Universitas Gadjah Mada for giving the permission to conduct this study through internship program in CICP; Haidar Buldan Thontowi, M.A and Banyu Wicaksono, S.Psi for their coaching in training of qualitative and quantitative content analysis; Nurul Aisya Berylia and Orysa Noor Azizah for their assistance in secretariat of CICP. 